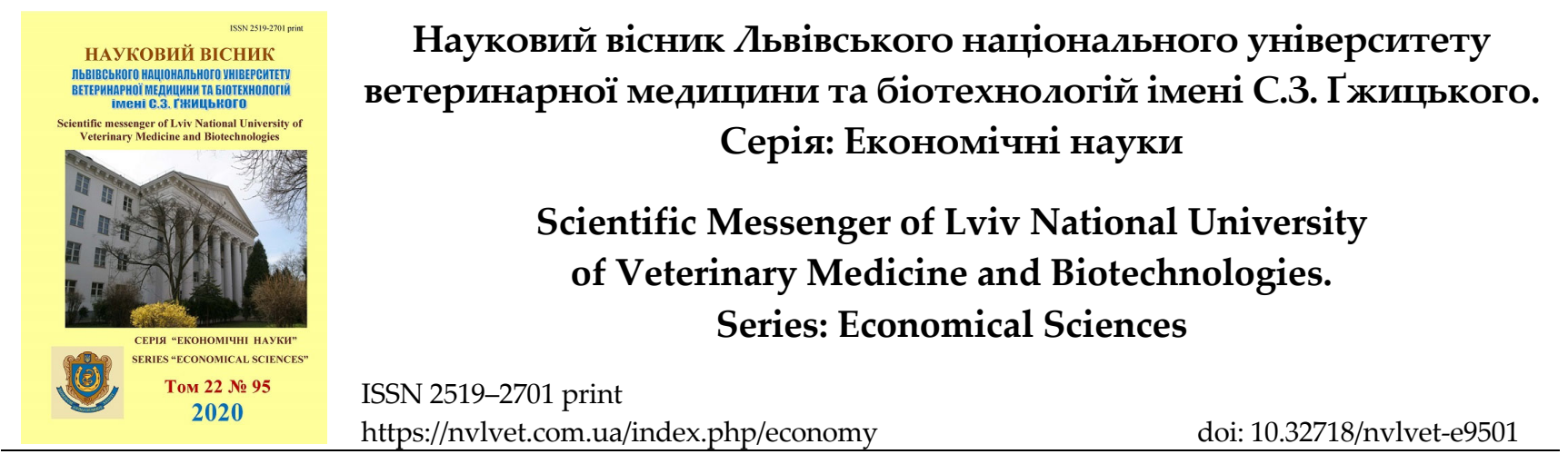

UDC 303.094:65.012.23

\title{
Information systems and technologies in the business process management
}

M. V. Vovk, O. V. Kindrat, O. Y. Hrymak

Stepan Gzhytskyi National University of Veterinary Medicine and Biotechnologies Lviv, Ukraine

Article info

Received 26.08.2020

Received in revised form 24.09.2020

Accepted 25.09.2020

Stepan Gzhytskyi National University of Veterinary Medicine and Biotechnologies Lviv, Pekarska Str., 50, Lviv, 79010, Ukraine.

Tel.: +38-067-75-282-52 $+38-067-721-76-35$

E-mail: mirkavovk21@gmail.com, olenakind@ukr.net
Vovk, M. V., \& Kindrat, O. V., \& Hrymak, O. Y. (2020). Information systems and technologies in the business process management. Scientific Messenger of Lviv National University of Veterinary Medicine and Biotechnologies. Series: Economical Sciences, 22(95), 3-9. doi: 10.32718/nvlvete9501

With the rapid development of information technologies and information economy ingeneral, effective information management determines the success of almost every business operation, and the choice of information and management decisions in general relieson IT managers. However, it is rather difficult for functional or line managers decidewhether it is important to participate in the formation of information strategy of their own business and whether they need to know what tools are available to turn a large array of information into business intelligence. This article is intended to reveal the important role of information and information resources in the activities of modern enterprises. The concepts of "data" and "information" are described. The data model and data types used by business information systems are described. The role of the database in the business process management system is revealed. It is indicated how important it is to form the information space of the enterprise correctly and choose the necessary software product for a particular enterprise. It is determined that the information system of the enterprise is based on the integrated use of potential and available information resources, taking into account their main features. The connections between the component of management systems are investigated and it is noted that the business process management system of the enterprise covers all levels of the enterprise. It is said that the enterprise may face different problems without data administration procedures. The types of information support using different levels of management are given. The internal and external information which his taken into account during making management decisions is characterized. It is proposed to invest in the management practice of developing an information strategy that significantly improves the management process and increases its efficiency. The typical structure of the proposed document and the role of information strategy regarding the levels of enterprise management are given.

Key words: information, information support, information system, information technologies, management, business processes, information strategy.

\section{Інформаційні системи та технології в управлінні бізнес-процесами}

\author{
М. В. Вовк, О. В. Кіндрат, О. Я. Гримак
}

Львівський національний університет ветеринарної медицини та біотехнологій імені С. 3. Гжиџького, м. Львів, Украӥна

Зі швидким розвитком інформаційних технологій та інформаційної економіки загалом ефективне управління інформацією визначає успіх практично кожної бізнес-операції, а вибір засобів прийняття інформаційних та управлінських рімень загалом покладається на IT-менеджерів. Проте постає питання, чи важливо для функиіональних чи лінійних менеджерів брати участь у формуванні інформаційної стратегії свого бізнесу та чи потрібно їм знати, які інструменти доступні для перетворення великого масиву інформацї̈ у бізнес-аналітику. Дана стаття покликана розкрити важливу роль інформацї та інформаційних ресурсів у діяльності сучасних підприсмств. Охарактеризовані поняття “дані” та “інформачія”. Описана модель даних та типи даних, щяо використовуються інформаиійними системами бізнесу. Розкрита роль бази даних в системі управління бізнес-процесами. Вказано, наскільки важливо правильно сформувати інформаційний простір підприємства та вибрати необхідний програмний продукт для 
конкретного підприємства. Зазначено, щзо інформаційна система підприємства повинна базуватися на комплексному використанні потенційних і наявних інформаџійних ресурсів з урахуванням їх основних особливостей. Досліджено зв'язки між складовими системи управління та зазначено, шо система управління бізнес-прочесами підприємства охоплює усі рівні роботи підприємства. Описані проблеми, з якими може зіткнутися система менеджменту без прочедур адміністрування даних. Наведені типи інформаційного забезпечення, шзо використовуються різними рівнями управління. Охарактеризована внутрішня та зовнішня інформація, яка береться до уваги при прийнятті управлінських рішень. Запропоновано ввести в практику управління підприємством розробку інформаційної стратегї, яка значно покращує процес управління та збільшує його ефективність. Подана типова структура запропонованого документу та зазначено роль інформаційної стратегї щьдо рівнів управління підприємством.

Ключові слова: інформачія, інформаџійне забезпечення, інформаційна система, інформачійні технології, управління, бізнеспроцеси, інформаџійна стратегія.

\section{Вступ}

Ефективне управління інформаційними потоками $\epsilon$ основною вимогою сучасного бізнесу. Воно допомагає перетворювати звичайну базу даних підприємств на корисну інформацію, забезпечує отримання переваг під час прогнозування, планування, контролю, а також підвищує ефективність бізнесу. Здавалося б, 3 позиції теорії менеджменту процеси управління інформацією на підприємстві можна повністю передавати третім особам. Проте менеджери, які вирішили передати аналіз інформації виключно технічним професіоналам, ставлять під загрозу обгрунтованість своїх управлінських рішень. Тому сьогодні менеджери повинні бути обізнані в сфері сучасних методів аналізу інформації, а також найновіших технологіях у галузі управління інформацією, щоб підвищити продуктивність свого підприємства і підтримувати його конкурентоспроможності на ринку.

Теоретичні і практичні аспекти управління на основі інформаційних систем і технологій висвітлені у наукових працях таких вчених, як Браян В., Бенсон В., Сидорова А., Гужва В., Бусленко Н., Жалдак М., Писаренко Т., Кваша Т., та ін. Питанням дослідження автоматизації бізнес-процесів займалися Ольшанський О., Сарай Н., Пригожин А., Завлін П. та ін. Науковці досліджували різні підходи щодо організації та автоматизації управлінського процесу та його складових, проте варто зазначити, що використання інформаційних систем i технологій у практиці, як інструменту реалізації процесів управління залишається недостатньо вивченим, що і обумовлює актуальність даного дослідження (Benson \& Tribe, 2008; Bryan, 2013; Sidorova et al., 2015; Pysarenko et al., 2015; Ol'shans'kyj, 2018; Saraj, 2020).

Метою статті є аналіз та обгрунтування ефективних засобів управління в сфері прийняття рішень та вдосконалення бізнес-процесів за допомогою інформаційних систем і технологій. Основними завданнями $\epsilon$ висвітлення важливості інформації та вимог до неї під час прийняття управлінських рішень; дослідження понять “дані” та “інформація"; розкрити роль “бази даних” як центрального елементу бізнес-процесів; дослідити такий елемент управління як “інформаційна стратегія”.

\section{Матеріал і методи досліджень}

У процесі дослідження було застосовано методи теоретичного узагальнення, системного аналізу та синтезу. Методи логічного узагальнення, групування i порівняння використано для вивчення управлінських процесів. Графічний метод застосовано для наочного подання схематичного зображення результатів досліджень.

\section{Результати та їх обговорення}

Сучасні підприємства використовують та генерують величезну кількість інформації. 3 кожним днем інформація стає найціннішим ресурсом для бізнесу. Інформація використовується при здійсненні поточних ділових операцій, застосовується у сфері прийняття рішень та супроводжує майже весь процес управління в сучасному бізнесі.

Розробка і прийняття управлінських рішень $\epsilon$ складним процесом, здійснення якого повинно опиратися на повну та достовірну інформацію, адже інформаційне навантаження на апарат управління щоденно зростає, що часто призводить до випадання 3 поля зору важливих тенденцій. У цьому плані значну роль слід надавати інформаційному забезпеченню системи управління підприємством, ефективність якого визначає кінцеву результативність його функціонування. (Lavruk \& Lavruk, 2011).

Це вимагає від підприємства все більше інвестицій в інформаційні передові технології, оскільки вони формують економічну ефективність бізнесу. Ця економічна ефективність може бути виражена через підвищення конкурентоспроможності, збільшення продуктивності праці, зростання доходу тощо.

Якщо інформація представляє вартість, іiі можна вважати активом. Незважаючи на те, що ніхто не може відчути чи доторкнутися до інформації, вона $є$ критично важливим елементом у сучасному бізнесі. Інформація може бути активом або ресурсом, залежно від прийнятої інформаційної стратегії або зовнішніх факторів.

Визначення інформації є основою для формування та розуміння суті цього поняття, а в подальшому оцінки важливості широкого і своєчасного впровадження та функціонування інформаційних систем в бізнесі та економіці загалом. Особливо важливо розуміти різницю між даними, інформацією та знаннями, а також усвідомлювати, як вони допомагають організаціям досягти своїх бізнес-інтересів.

Різниця між даними та інформацією визначається головним чином тим, як вони використовуються в бізнес-контексті. Окремий запис у квитанції про продаж, який містить назву товару, кількість та ціну, не стає “інформативним” для бізнесу, якщо це не $є$ його кінцевою метою. Різниця між даними та інформацією 
стає зрозумілішою при перетворенні даних в інформацію для комерційних цілей, тобто коли обробляються окремі записи даних та до вихідних даних додається якесь значення корисності, що перетворює їх на ділову інформацію.

Для того, щоб бути корисними в бізнес-процесах, дані, що використовуються в управлінні, впорядковуються за допомогою процесу моделювання. Модель даних забезпечує набір принципів організації даних. Протягом десятиліть найпопулярніша модель даних, яка використовується для зберігання даних в організаціях, базується на файлах. У цій моделі даних для організації даних використовуються логічно організовані конструкції полів (елементів даних), записів (елементів даних) та файлів (структур даних). У контексті файлової моделі запис можна вважати елементом даних. Структура (або так званий синтаксис) типового запису складається 3 набору елементів даних, які зазвичай становляють значущу сутність.

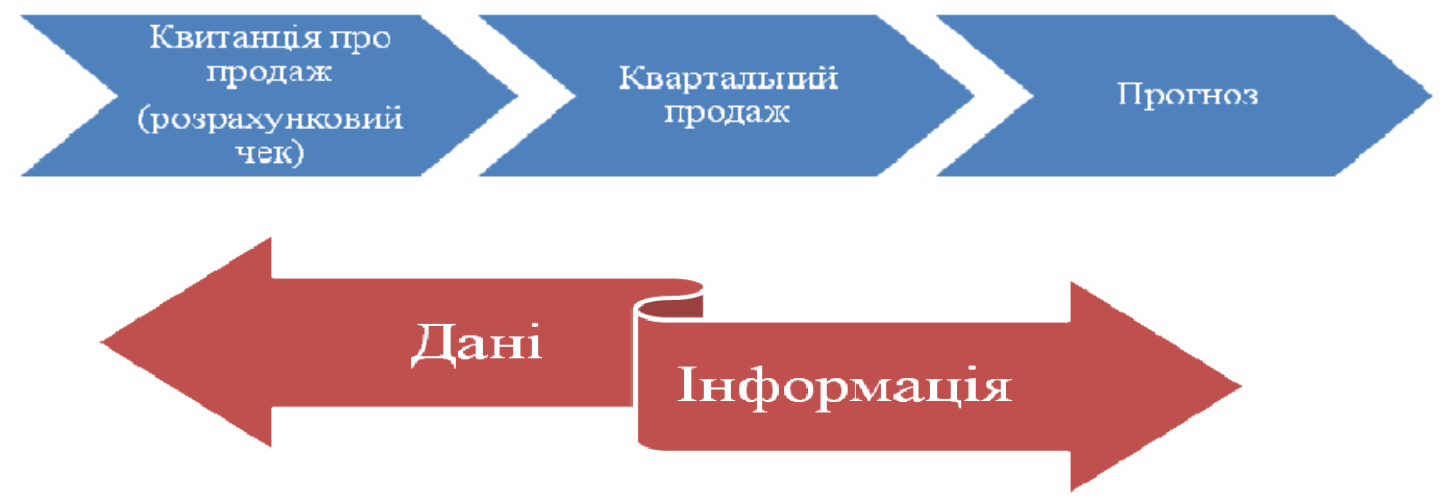

Рис. 1. Дані та інформація: надходження до прогнозу продажів (Bourgeois, 2019)

Організація записів у певному файлі разом означає, що існує певна залежність між елементами даних. Наприклад, конкретна організація зберігає дані про свої замовлення у файловій формі. Різні записи замовлень можуть зберігатися в різних файлах, щоб створити змістовні категорії. Або окремі файли можуть містити записи про замовлення, розміщені в різні роки, чи оброблятися різними продавцямиконсультантами. Тому конкретна модель даних сама надає якийсь сенс даним (Bourgeois, 2019).

У моделі даних модель окремого елемента даних характеризується якимсь форматом, який зазвичай називають його типом даних. Тип даних вказує не тільки прийнятну форму елемента даних, а також його формат та можливий діапазон. Крім того, тип даних показує відповідні можливі операції на елементі даних.
На сьогодні існує низка стандартних типів даних. Типи даних, які зазвичай використовують інформаційні системи бізнесу, включають цифри, текст, дату і час та інші. Проте в останні роки стало неможливим зберігати дані лише у стандартних типах даних. Сучасні інформаційні системи повинні включати графічні, аудіо- та відеодані. Це призвело до розробки нових типів даних, що дозволяють кодувати ширший спектр даних у цифровій формі.

Як уже зазначалося, інформація може бути у різних формах і зберігається в різних каналах. Корпоративна база даних часто стає центром ділових операцій та прийняття рішень. Деякі або всі сфери бізнесу можуть спиратися на інформацію, що зберігається в центральній базі даних, як показано на рис. 2.

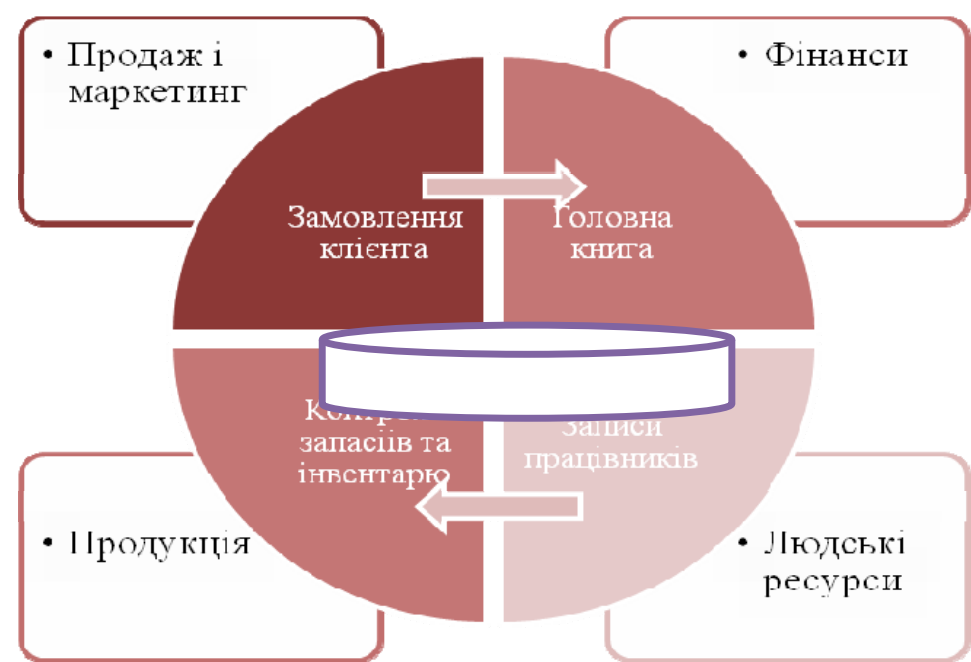

Рис. 2. База даних у центрі бізнес-функцій.

Джерело: систематизовано автором на основі (Bourgeois, 2019) 
Відділ продажів зберігає дані про замовлення клієнтів. Фінанси та бухгалтерія використовують дані про продаж для формування рахунків-фактур та обробки платежів. Відділ маркетингу використовує дані про клієнтів та інформацію про продажі для ефективних маркетингових кампаній. Кадрові ресурси зберігають інформацію про працівників компанії, їхні навички та потреби у професійному розвитку. Центральна база даних полегшує відстеження запасів та рівня виробництва для виробничих та виробничих сфер бізнесу. Централізована інформація допомагає навіть малому бізнесу ефективно працювати з інформацією в режимі реального часу.

Хоча більшість вважає базу даних головним джерелом інформації в бізнесі, значна кількість інформації насправді $\epsilon$ неструктурованою та децентралізованою. Неструктуровані джерела даних включають документи, електронні таблиці, електронні листи, презентації, інтранет та веб-сторінки. Інколи кажуть, що інформація розподіляється між різними джерелами та сферами бізнесу. Децентралізована інформація розміщується на ноутбуках, мобільних телефонах, настільних ПК, персональних пристроях.

У багатьох організаціях джерела даних розкидані по різних підрозділах. Проте без загально організаційного плану та процедур адміністрування даних управління може зіткнутися з такими проблемами, як:

$>$ Завелика кількість даних - коли дані дублюються та зберігаються у декількох місцях у більше ніж одному файлі;

$>$ Погана доступність до даних - дані стають ізольованими та доступними лише власнику певного файлу у файловій системі. Обмін даними та їхня видимість для працівників зменшується;

$>$ Погана безпека даних - дані, що поширюються в організації в різних формах і місцях, зменшують можливість бізнесу встановлювати належний контроль безпеки та забезпечувати авторизований доступ до інформації;

$>$ Помилкові дані - коли однакові дані існують у багатьох місцях, вони стають вразливішими до людських помилок, спричинених різними працівниками, i помилки зазвичай залишаються непоміченими довше.

Традиційно уся система менеджменту підприємства поділяється на три рівні. Це операційний, управлінський та стратегічний рівні. Вони існують майже на всіх підприємствах, незалежно від їхнього розміру або сектору діяльності, хоча в невеликих компаніях деякі рівні можуть збігатися.

На операційному рівні приймаються рішення щодо забезпечення безперебійного функціонування операційних процесів або поточного управління. На цьому рівні необхідно стежити за тим, щоб ресурси використовувались ефективно, проводилась інвентаризація запасів, рівні виробництва відповідають запланованим і т. д. Для прийняття рішень на цьому рівні у більшості випадків потрібна внутрішня інформація.
Інформація для прийняття рішень на управлінському рівні має типовий часовий проміжок - від кількох тижнів до декількох місяців або року. Середній управлінський рівень зазвичай контролює середньострокові операції планування, прогнозування та складання бюджету. Вони використовують внутрішню, а також випадкову зовнішню інформацію. Наприклад, встановлення квартального бюджету вимагає знання поточних видатків, а також зовнішньої інформації про ціни.

Управління на найвищому стратегічному рівні зосереджується на загальних або стратегічних питаннях, пов'язаних із загальним розвитком підприємства в довгостроковій перспективі. На цьому рівні рішення зазвичай стосуються довгострокових питань, таких як реструктуризація, фінансові інвестиції та інші стратегічні заходи, пов'язані з майбутнім, а не 3 поточним управлінням. Інформація, необхідна для прийняття рішень на цьому рівні, всебічно збирається не тільки 3 внутрішніх джерел самого підприємства, а й також включає зовнішню інформацію, таку, як дані, що стосуються економічної ситуації або галузей в цілому.

Враховуючи все вищесказане, з'являється тенденція до цілісного й ефективного управління інформацією на підприємстві, яке повинне бути “уречевлене” в певному документі. Сучасні підприємства, особливо в умовах кризи, могли б орієнтуватися на американський досвід та розробляти інформаційну стратегію, щоб встановити, як ефективно управляти інформацією та дотримуватися законодавчих норм. Інформаційна стратегія - це плановий документ, який зазвичай створюється на стратегічному рівні головним інформаційним директором (ІТ-директором), можливо, разом із керівником відділу технологій (IT) та ITменеджером.

Інформаційна стратегія розроблена для підтримки загальної ділової стратегії підприємства та пояснює, як інформацію слід фіксувати, обробляти, використовувати та розпоряджатися нею протягом ії життєвого циклу. Незважаючи на те, що структура інформаційної стратегії зазвичай відрізняється на різних підприємствах, є деякі загальні пункти, які включені до більшості документів інформаційної стратегії (табл. 1) (Benson \& Tribe, 2008).

Для надання конкретних рекомендацій своїм працівникам, підрядникам, торговим партнерам та іншим зовнішнім зацікавленим сторонам щодо обробки, зберігання та передачі різних типів інформації, підприємства зазвичай складають документ про інформаційну політику. Цей документ надзвичайно важливий, коли організація обробляє конфіденційні дані, що відповідають безпеці, або підпорядковується урядовим вказівкам щодо обробки інформації. Він визначає рівні чутливості інформації та перелічує, хто має доступ до кожного рівня. Метою інформаційної політики $\epsilon$ забезпечення належного захисту інформаційних активів підприємства від загроз або розголошення. 


\section{Таблищя 1}

Типова структура документа про інформаційну стратегію

\begin{tabular}{ll}
\hline \multicolumn{1}{c}{ Побудова } & \multicolumn{1}{c}{ Мета } \\
\hline Огляд інформації та ресурси & $\begin{array}{l}\text { Короткий зміст про стан ресурсів, їх використання внутрішніми та зовнішніми } \\
\text { користувачами, ключові проекти, бюджетування тощо } \\
\text { Інформаційна будова та }\end{array}$ \\
ІТ структура & Опис ІТ-інфраструктури, ключові проекти, деталізація джерел даних та їх призначення \\
Зовнішні фактори & Аналіз конкуренції, економіки, державної політики та технологічні досягнення \\
Можливості & Аналіз нових можливостей для бізнесу, що випливають з інформації та технологій \\
Аналіз ризиків & Опис внутрішніх та зовнішніх загроз, аналіз \\
Впровадження & дотримання нормативних актів, короткий опис використання інформації конкурентами \\
Дерелік основних етапів впровадження, а також аналіз стану виконання інформаційної \\
Джерело: вдосконалено автором на основі (Benson \& Tribe, 2008)
\end{tabular}

Варто зазначити, що досвід розробки та впровадження інформаційної стратегії підприємства було апробовано в практичній діяльності вітчизняних підприємств сфери управлінського консалтингу, що дозволило досягти позитивних результатів для підприємств-клієнтів консалтингових компаній, зокрема: чіткіше розуміння інформаційних потреб підприємств менеджерами та функціональними робітниками, ефективніше інформаційне забезпечення діяльності підприємства, досягнення стану узгодженості всіх елементів операційної системи підприємства та їі організаційної структури із системою інформаційного забезпечення діяльності підприємства (Grebeshkov, 2010).

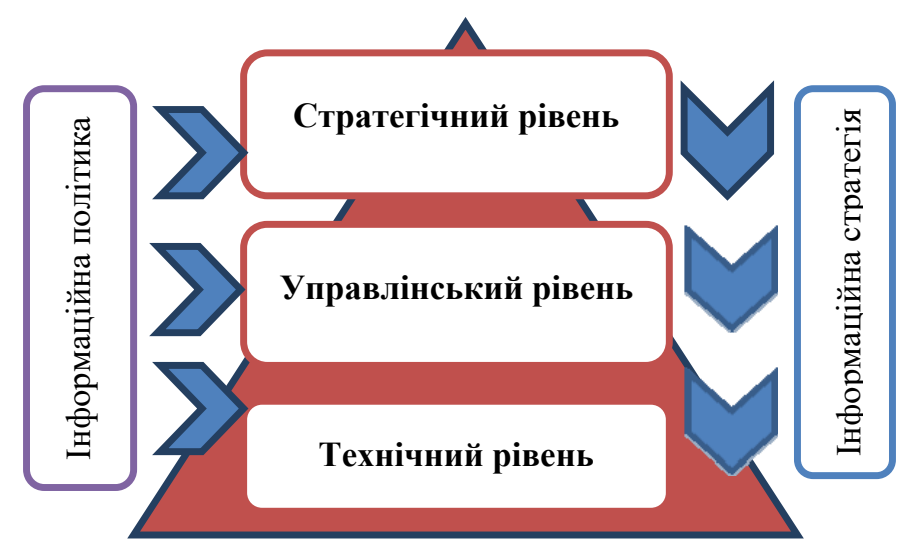

Рис. 3. Місце інформаційної стратегії щодо рівнів управління (Benson \& Tribe, 2008)

Для ефективного управління інформаційним бізнесом організації використовують широкий спектр програмних забезпечень: від простих електронних таблиць до складних систем планування ресурсів підприємства. Сучасні розробки у сфері програмного забезпечення допомагають підприємствам отримувати цінність зі своїх інформаційних активів. У наведеній нижче таблиці наводиться перелік різних типів інформаційного забезпечення та їх застосування на підприємстві.

Застосування того чи іншого виду інформаційного забезпечення має бути синхронізоване зі стратегічним плануванням і системою бюджетування підприємства на основі розробки ефективного механізму управління бізнес-процесами 3 урахуванням ресурсних можливостей i обмежень, що дозволить підприємству перейти на новий якісний рівень управління (Jurchuk, 2018).

Сучасність вимагає все більшого впровадження інноваційних технологій на підприємствах. А це необхідний регулярний i безперервний процес, що включає такі етапи:

- пошук нових ідей, технологій, рішень;

- апробація технологій в діяльності підприємства на невеликій ділянці;

- застосування технології в масштабах всього підприємства;

- оцінка окупності від застосування інноваційної технології.

Отже, сьогоднішні інформація стала основним рушієм конкуренції та виживання в сучасній системі господарювання. Управління інформаційним бізнесом стає однією із найважливіших управлінських функцій. 


\section{Таблищя 2}

Приклади інформаційного забезпечення для обробки даних на підприємстві

\begin{tabular}{|c|c|c|c|}
\hline Назва & Приклади & Призначення & $\begin{array}{c}\text { Рівні } \\
\text { застосування } \\
\end{array}$ \\
\hline \multirow{2}{*}{ Таблиці } & Електронні таблиці & $\begin{array}{l}\text { Призначені для введення та аналізу даних, їх автоматичних } \\
\text { обробок та інших аналітичних можливостей }\end{array}$ & Операційний \\
\hline & Веб-таблиці & $\begin{array}{l}\text { Дає можливість онлайн-співпраці, дозволяючи спільне реда- } \\
\text { гування кількома користувачами }\end{array}$ & Операційний \\
\hline \multirow{3}{*}{$\begin{array}{l}\text { Системи } \\
\text { баз даних }\end{array}$} & $\begin{array}{l}\text { Система управління } \\
\text { базами даних }\end{array}$ & $\begin{array}{l}\text { Дозволяє ефективно управляти, захищати та аналізувати дані, } \\
\text { а також взаємодіяти з іншими програмними додатками }\end{array}$ & $\begin{array}{c}\text { Операційний } \\
\text { Управлінський }\end{array}$ \\
\hline & Сховища даних & $\begin{array}{l}\text { Збирає дані з кількох оперативних баз даних, обробляє та } \\
\text { підтримує операції на всьому підприємстві }\end{array}$ & $\begin{array}{l}\text { Операційний } \\
\text { Управлінський } \\
\text { Стратегічний }\end{array}$ \\
\hline & $\begin{array}{c}\text { Аналітична обробка у } \\
\text { реальному часі }\end{array}$ & $\begin{array}{l}\text { Дозволяє переглядати та отримувати інформацію за допомо- } \\
\text { гою багатовимірного аналізу даних }\end{array}$ & $\begin{array}{l}\text { Управлінський } \\
\text { Стратегічний }\end{array}$ \\
\hline \multirow{2}{*}{$\begin{array}{l}\text { Комунікації } \\
\text { та співпраця }\end{array}$} & $\begin{array}{l}\text { Інтернет, блоги, } \\
\text { соціальні мережі }\end{array}$ & Підтримка розповсюдження інформації на підприємстві & Операційний \\
\hline & $\begin{array}{l}\text { Електронна пошта, } \\
\text { відео-конференції }\end{array}$ & Комунікації та співпраця & Операційний \\
\hline \multirow[t]{3}{*}{$\begin{array}{l}\text { Спеціалізовані } \\
\text { системи }\end{array}$} & $\begin{array}{c}\text { Планування ресурсів } \\
\text { підприємства }\end{array}$ & $\begin{array}{l}\text { Корпоративна інформаційна система, призначена для комплекс- } \\
\text { ного підходу до управління даними підприємства шляхом інтег- } \\
\text { рації інформації про фінанси, продажі, людські ресурси. }\end{array}$ & $\begin{array}{c}\text { Операційний } \\
\text { Управлінський } \\
\text { Стратегічний } \\
\end{array}$ \\
\hline & $\begin{array}{c}\text { Координація відносин } \\
\text { з клієнтами }\end{array}$ & $\begin{array}{l}\text { Використовується для координації взаємовідносин зі спожи- } \\
\text { вачами і включає збір, аналіз та зберігання інформації про } \\
\text { споживачів, постачальників і партнерів. }\end{array}$ & $\begin{array}{c}\text { Операційний } \\
\text { Управлінський } \\
\text { Стратегічний }\end{array}$ \\
\hline & Управління знаннями & $\begin{array}{l}\text { Забезпечує функціональність та розподіл знань, необхідних } \\
\text { для успіху організації. }\end{array}$ & $\begin{array}{l}\text { Операційний } \\
\text { Управлінський } \\
\text { Стратегічний }\end{array}$ \\
\hline
\end{tabular}

Джерело: систематизовано автором на основі (Benson \& Tribe, 2008)

\section{Висновки}

Інформація є основою діяльності та виживання для будь-якого сучасного підприємства. Інформація відрізняється від даних в результаті операцій обробки даних. Після того, як дані обробляються та формуються у значущій формі, корисній для підприємства, вони перетворюються на інформацію. Для того, щоб бути корисними для підприємств дані зазвичай організовуються за допомогою певної моделі даних. Модель даних визначає, як елементи даних упорядковані в ієрархію, що складається $з$ елементів даних та структур даних. Елементи даних характеризуються типом даних. Стандартні типи даних включають числа, текст, одиниці дати та часу, тепер доступні більш складні типи даних.

Для того, щоб розрізнити різні типи інформації, яка обробляється та генерується на підприємствах, необхідно розрізняти стратегічний, управлінський та операційний рівні управління. Інформація, необхідна на кожному рівні, відрізняється своїм походженням (зовнішнім чи внутрішнім), часовими рамками (довгострокова, середньострокова чи короткострокова), рівнем деталізації тощо. Про те, як підприємство узгоджує свої інформаційні активи зі своїми бізнесцілями, вказано в документі про інформаційну стратегію.

Перспективи подальших досліджень. Постійно зростаюча складність сучасного бізнесу 3 кожним роком призводитиме до появи ще ширшого спектру програмного забезпечення, яке призначатиметься для того, щоб допомогти підприємству отримати користь від своїх інформаційних активів. Таке програмне забезпечення утворюватиме бази даних для інтегрованих систем планування ресурсів на підприємствах, де все частіше робитиметься акцент на співпраці та комунікаційних функціях сучасного програмного забезпечення.

\section{References}

Aalst, W. M. P., La Rosa, M., \& Santoro, F. M. (2016). Business Process Management. Bus Inf Syst Eng, 58, 1-6. doi: 10.1007/s12599-015-0409-x.

Benson, V., \& Tribe, K. (2008). Business Information Management. Bookboon.

Bourgeois, D. (2019). Information Systems for Business and Beyond. URL: https://opentextbook.site/exports/ ISBB-2019.pdf.

Bryan, V. (2013). Information technology management. http://jgwill.com/fichiers/Chapter-14-InformationTechnology-Management.pdf.

Dmytriv, K. I., \& Shpak, Ju. N. (2017). Doslidzhennja informacijnyh system $\mathrm{v}$ upravlinni pidpryjemstvamy: dosvid ta perspektyvy. Ekonomichnyj visnyk Nacional'nogo tehnichnogo universytetu Ukrai'ny "Kyi'vs'kyj politehnichnyj instytut", 14, 231-239. doi: $10.20535 / 2307-5651.14 .2017 .108776$ (in Ukrainian).

Grebeshkov, O. M. (2010). Metodychni pidhody do rozrobky ta vprovadzhennja informacijnoi' strategii' pidpryjemstva. Efektyvna ekonomika, 12. URL: http://www.economy.nayka.com.ua/?op $=1 \& z=414$ (inUkrainian).

Jurchuk, N. P. (2018). Informacijni systemy i tehnologii' jak innovacija u systemi upravlinnja biznes- 
procesamy. Efektyvna ekonomika, 5. URL: http://www.economy.nayka.com.ua/?op=1\&z=6323 (in Ukrainian).

Lavruk, L. V., \& Lavruk, O. S. (2011). Informacijne zabezpechennja systemy upravlinnja pidpryjemstvom. Zbirnyk naukovyh prac' Podil's'kogo derzhavnogo agrarno-tehnichnogo universytetu, 19, 171-176. http://nbuv.gov.ua/UJRN/ZnpPdatu_2011_19_43 (in Ukrainian).

Ol'shans'kyj, O. V. (2018). Rozrobka metodiv udoskonalennja upravlinnja biznes-procesamy pidpryjemstv. Tehnologichnyj audyt ta rezervy vyrobnyctva, 5(4(43)), 20-25. doi: 10.15587/23128372.2018.146862 (in Ukrainian).

Pysarenko, T. V., Kvasha, T. K., Bereznjak, N. V., \& Prudka O. V. (2015). Informacijne zabezpechennja in- novacijnogo rozvytku: svitovyj ta vitchyznjanyj dosvid. [Monografija]. K.: UkrINTEI (inUkrainian).

Rahimi, F., Møller, C., \& Hvam, L. (2016). Business process management and IT management: The missing integration. International Journal of Information Management, 36(1), 142-154. doi: 10.1016/j.ijinfomgt.2015.10.004.

Saraj, N. I. (2020). Optymizacija upravlinnja biznesprocesamy na pidpryjemstvi. Innovacijna ekonomika, 1-2, 79-84. doi: 10.37332/2309-1533.2020.1-2.12 (inUkrainian).

Sidorova, A., Torres, R., \& Beayeyz, A. A. (2015). The Role of Information Technology in Business Process Management. In: vom Brocke J., Rosemann M. (eds) Handbook on Business Process Management 1. International Handbooks on Information Systems. Springer, Berlin, Heidelberg, 421-444. doi: 10.1007/978-3-642-45100-3_18. 